\section{MEDICAL AND SURGICAL ACHIEVEMENT IN THE U.S.S.R. DURING WAR*}

\section{By E. ROCK CARLING}

$\mathrm{W}$ HEN the fighting was at its height in Crete, 2,164 years ago, the people of Knossos applied to those of Cos, then the leading medical school in the world, for a military surgeon. Hermias, who was sent, did his duty so well that he not only saved many lives, but also by his example sustained the morale of the troops and thus contributed to victory. An inscription acknowledging his merits with gratitude is extant in Cos to this day, unless the Germans have recently removed it to grace one of their museums.

The duties of military doctors differ from those of their civilian colleagues. To relieve suffering, to save life, and to restore function, are indeed a part of their task; but there is an overriding duty-to keep every possible man in the firing line, and to return every possible man to that line at the earliest moment after injury or sickness. This may mean, for example, that a lightly wounded man has priority for attention over one so gravely injured that, though he recover, he will never return to the front.

More men leave the front as the result of sickness than of wounds. Sickness has determined many campaigns since that of Hannibal against Rome, and doubtless many before it. Thus a supremely important but undramatic part of the military medical officer's duty is concerned with sanitation in all its aspects, with such things as water supplies, and particularly with 'prevention'; from the control of flies, mosquitoes and other pests, to inoculation against specific diseases like tetanus, typhoid, yellow fever, and so on.

Modern implements of war, in their design, require the aid of physiologists and medical specialists if their full efficiency is to be achieved. It is idle to fabricate very powerful machines unless their control is within the physiological capacity of those who are to use them. In many cases elaborate measures must be devised to extend the limits of normal human functions. To endure extremes of temperature or to protect against them; to ensure co-ordination of the sensations and reactions in the atmospheric conditions of high altitudes and at great depths ; to perfect the adaptation of vision to dim light; to control, or sometimes for offensive purposes to enhance, the means of illumination and dazzle; to protect against, and incidentally to find means to evade the possibility of protection against, flame as a weapon of offence; to perfect the means of audible communication amidst external din; to concentrate nourishment in palatable form within restricted limits of weight; to find means of minimizing the effects of rapid acceleration and deceleration of the body, and of the motions which produce sea and air sickness. These and many similar tasks called urgently for further consideration by several committees of the Medical Research Council in Britain at the outbreak of war, and concurrently with the rapid. development of the machines have demanded continuing intensive research. The Russians have, so far, not emulated our other Allies in pooling the results of their researches; but it is certain from the success that has attended their corresponding weapons

* Substance of a Friday evening discourse at the Royal Institution delivered on February 25. in the field, and indeed their whole military effort, that they have solved the problems which have beset us. Like ourselves, they have mobilized the resources of their physiological, pathological and other research departments to promote the efficiency of their military forces.

The Russian is a man with a realistic sense of the main chance, and the Soviet military surgeon, like others, believes in prevention at all costs. Thus it is that the Russian soldier of the Red Army finds himself better prepared to face the rigours of winter than his counterpart in the vaunted German military machine. If one sees, as one may, ill-shod folk in the streets of Moscow, it is because the soldier must have the best footwear if he is to sustain, in wet, cold and rough going, the sternest tests. No civilian in Russia grudges sacrifice or discomfort or hardship that is the outcome of the soldier's necessity. The Red Army is the darling of the nation. The people have unshakable confidence in it. It is perhaps the knowledge of the implicit trust reposed in them by their own people that inspires the Soviet soldier to such heroic deeds, to such wonderful feats of endurance. To have created such morale in people and army alike is one of the major achievements of Marshal Stalin and those who serve him.

Of the actual achievements of the Red Army doctors we shall not know in full until years after the War, when medical history is written. All I can do is describe what we of the Surgical Mission saw and did not see (though we looked for it), in our carefully conducted visit to the Red Army. In the South African Campaign $I$ was plunged into a devastating epidemic of typhoid fever at its height. I know what it does to an army and the strain it puts upon the medical corps. In the War of 1914-18 I learned what a very different picture is presented at an advanced C.C.S. when wounded men are streaming in from victory or dragging wearily back from unsuccessful fighting. In this War it has been my rather tragic duty to witness in most of the heavily attacked cities the effect of bombing on civilians of all classes. I have been privileged to see and hear a good deal of the most modern accomplishments of our own and our Allies in war surgery and medicine. My companions on the Mission were men of similar experience and knew what to look for. With that background, then, what did the Russian picture reveal ?

A first estimate of the achievements of military medicine in the U.S.S.R. may be deduced from the fact that the Red Armies are still in the field and victorious after retreats of depressing magnitude. There are authenticated examples in history of the collapse of good troops in the face of epidemic sickness and mass casualties, simply and solely because of the absence of a competent medical personnel. It is certain that the Russian soldier must have been well cared for; it is certain that the organization and the standard of service we witnessed must have extended, if not quite at the level chosen for demonstration to foreigners, yet at approximately that level along all the fronts, and throughout the territory to which troops found their way.

The People's Commissar of Health claimed that the U.S.S.R. have practically abolished two of the greatest scourges of armies in the field : one universal on modern battlefields - gas-gangrene-and the other, formerly endemic in a great part of the territory over which their fighting spreads-typhus fever. He told us that since the fighting began there has been no 
cholera. He also claimed that they get 70 per cent of their wounded back into the firing line-a figure not reached elsewhere. Probably we get between 60 and 70 per cent back into service, but not all of them into the front line. How have these feats been accomplished?

I am not prepared to admit as yet that either typhus or gas-gangrene has been entirely prevented, or treated with such uniform success as might appear from the claims put forward; but undoubtedly the Russians have controlled typhus epidemics where they might have devastated an army ; and they acknowledge the same methods we ourselves employ in the mitigation of gas-gangrene. It may be that they have other and better methods than those disclosed; but so far, the allied medical corps are unaware of them, or of documented reports that justify confidence in their existence. On the other hand, the traditions of Russian research are so great, and the devotion of the Soviet authorities to-day to research in every field so intense, that there is nothing inherently improbable in a claim which perhaps can only be publicly substantiated after the War.

In connexion with those research traditions, one may consider three names, those of Mendeléeff, Metchnikoff and Pavlov. First, that of Mendeléeff, upon whose fundamental work much of modern chemistry rests; remotely, but veritably, he laid foundations upon which modern biochemistry has been built, with all that the sulphonamide drugs have accomplished by way of lessening the horrors and the tragedies of the battlefields. It is not such a far cry from the recognition of atomic numbers and the Periodic Law to the production to-day by the ultrasonic generator of microcrystals no more than eight times the size of a red blood corpuscle by Prof. Paramanov. Nor to the fabrication of emulsions by Prof. Lossovsky, which, by the aid of chemical stabilizers, gradually dispense with more and more oil until they are almost wholly aqueous. Both these methods permit safer use of sulphonamides intravenously; indeed, in one respect they have gone farther than we-injection into the arterial as well as the venous stream. This is the appropriate place to mention penicillin. The Russians having hitherto scarcely any supply, though our Mission took a small quantity, Prof. H. W. Florey has been sent to Moscow with a considerable quantity of the drug and all his knowledge. That is one of the gestures made by the British and American Governments to convince the Russians we are ready to put all our resources, all our discoveries in any science, at their disposal. of course, we should welcome reciprocal trust.

Metchnikoff, who worked largely in Paris, made great contributions both to bacteriology and to the understanding of the natural defences of the body against infection, which we now exploit by every means that can be devised. It is in the tradition of his work that the attention of Russian research should be directed not only to the control of infecting organisms by bacteriophages and bacteriostatic agents, but also to new methods of stimulating the defensive mechanism. For that purpose they are exploiting 'activators' of various kinds. Prof. Bogomouletz produces sera by injection into horses of splenic and lymphatic tissue, and finds that their action upon mesoblastic structures, particularly the vascular network, materially stimulates repair. They use the sera to promote healing of gastric ulcers and also to diminish the period of repair of wounds. They claim something like a 20 per cent reduction of invalidity-time in cases of fractures and gross softpart wounds.

They have other methods of producing the same effect, by burying under the skin partially ischæmic cutaneous flaps or placental tissue prepared by a chemical treatment. Extracts of placental tissue are also employed to hasten the 'taking' and the growth of skin-grafts. We saw these methods in use in the wards of Profs. Louria and Friedland.

Pavlov, whose contributions to physiological psychology introduced the element of measurement and exact observation necessary for all scientific advances, clarified a wide field of mental processes ; he trained a school of Russian psychologists whose labours in their turn have been fully employed by the Red Army medical authorities in the training, conservation and care of their man-power. One example from their system of rehabilitation of the lightly wounded soldier struck me forcibly. These men go to special hospitals where curative measures, both operative and physiotherapeutic, are employed. There, 'education' accompanies their progress and serves a twofold purpose. A man may return to his regiment fully restored to his former vigour; but he rejoins men who have had further experience that he has not shared. To that extent he is at a disadvantage and his sense of this particular inferiority may be deflected to the past disahility, which he had far better forget. The Russians, therefore, see to it that his rehabilitation education shall make him more expert than ever in the use of his weapons; better acquainted with the enemy methods and weapons he has to meet, and familiar particularly with the latest type of offensive machines of all kinds, and with the drill necessary for their most effective use. He then goes to his regiment with something his comrades do not possess, the last word in means for defeating and destroying the enemy; he has at least one source of superiority and his morale is that much heightened.

Fven to so elementary a medical requisite as cleanliness, the Russians add a psychological twist. Wounded men come in extremely dirty and often with several days' growth of beard. So, upon entry to the reception ward they find a 'barber'- not an orderly turned hair-cutter but a professional coiffeur who shaves them skilfully, cuts and shampoos the hair and starts the sequence which restores a man's self-respect. Thence they pass, after a drink of vodka, to the care of nurses, who bathe those who cannot manage for themselves-they have a real nursery 'tub' - and provide them with a clean set of underclothes or pyjamas. Only then, when they feel respectable again, does examination, sorting, dressing, begin. The cleanliness and warmth go some way towards 'resuscitation' of cases suffering largely from the fatigue, exposure and thirst which account for a good deal of the minor degree of shock. Of course, some cases are far too seriously ill to undergo this whole process; but wounds as such are no bar, for they are covered with waterproof bags or 'jackets', and in the case of broken legs the patient is put upon a slatted wooden stretcher before immersion and the limb can be completely steadied by ties to the slats. A good wash restores morale. These examples, trivial as they are, illustrate the realistic attitude of the Russians and the intelligence with which their problems are attacked. Their psychology, theoretical and applied, is far from being at fault. Perhaps the success of their propaganda has prepared us for appreciation of their psychological methods with the soldier. 
In my youth there was a famous book (Hilton on "Rest and Pain"), the theme of which was advocacy of immobilization; it held sway and governed practice for a generation. "Rest must be secured if pain is to be abolished." The pendulum of opinion swung and the supreme importance of early movement after injury was taught by the foremost surgeons of the day. We all know rather more precisely now when to employ rest and when movement.

In the recent Spanish War, a very well-known surgeon of Barcelona, Trueta-happily and fruitfully working among us now-advocated the treatment of gross injuries of the limbs, and especially fractures, by so close an application of plaster-of-Paris cases that all movement of the muscles of the limb was inhibited. Called the 'skin-tight plaster', it fitted like a glove. He advocated and secured 'rest', and the immobility of the muscles was so perfect that the pumping action which they normally exert upon the veins and lymphatics was abolished, and thus poisonous substances fabricated in the wounds failed to reach the general circulation, where their toxic effects would endanger the life of the patient. The principle is one which makes imperative meticulous observation of certain essential preliminaries in the way of operation and treatment; but in appropriate cir cumstances, the method is now very widely used in the Allied Armies and probably in those of the Axis, too. There was an earlier protagonist of a form of this expedient, an American, Winnett-Orr, to whom surgery owes very much, but the actual initiator of the close-plaster was a Russian. Pirogoff, whose name is known to every British medical student as the originator of a particular type of amputation which bears his name in our text-books, has been described as the "greatest Russian surgeon, and one of the greatest of all military surgeons". $\mathrm{He}$ used plaster-of-Paris for fractures in the Crimean War. He had noticed the use of plaster by a sculptor and realized at once how it could be adapted to war injuries. He wrote repeatedly on the subject, but years later lamented that neither French nor Italian military surgeons knew of his method.

Pirogoff's contributions to surgery were many. One more may be mentioned. Perhaps only after hearing of Florence Nightingale, but at any rate, in the Crimean campaign, with the help of one of the Grand Duchesses, he introduced nurses into military hospitals of the Russian Army.

Nursing means rather more in Russia at war than it does with us. Not more than our nurses would certainly volunteer to do did the necessity arise; scarcely more than they were ready to do in North Africa : but the position of women is a little different in the Soviet State in peace as well as in war. It is, 1 think, fair to say that the concession to women in the U.S.S.R. of exactly the same 'rights' as men has led to the full acceptance by them of their implied duties. Nurses go not only to the front-line hospitals, but also up to main dressing stations and into the line itself. They reach wounded men under fire, and drag or carry them to safety, and even if need be, defend their patients from enemy attack.

On our way to the front we found all the main road-crossings guarded by women soldiers carrying tommy-guns, and it was obvious that they would not have stood upon ceremony if our cars had not promptly obeyed the 'halt'! We did not, at the clearing hospital, see any armed nurses, but many women have been decorated for feats of bravery.

Of the versatility of the Russian nurses we had evidence enough. The story of their prowess with the axe, saw, plane and spade is now well known, and we witnessed it. The 2,000-bedded hospital in the pine-forest had at the time of our visit only about 700 patients, but the Orel advance was about to begin and expansion to 4,000-bed capacity was under way. The nurses not needed for their professional work were taking a full share in all the labours of construction, foundation digging, timber squaring, carpentry, camouflage and decoration. Very deft with their tools they seemed to be. It must not be forgotten that for our entertainment that evening those same women staged a very good cabaret show.

To judge of their proficiency in their proper sphere we had opportunity in operating theatres. It was manifest that the standard of the theatre sisters and their staffs was very high. As surgeons we felt that we should confidently work in theatres run by those women. In no hospital that we visited did we observe evidence of poor ward-work. Their bedsteads and mattresses are not so good as ours, and that makes nursing more exacting; demands more conscientious attention to detailed care; and I think we are entitled to infer that nursing is well done.

Organization is a strong point in the Russian of to-day. The basic plan of military hospitals is flexible; they are planned in units which may be grouped or detached at will; the staffing is so systematized that a unit sent forward from a base hospital can take over the whole or a section of a forward post. They have aimed at 'leap-frogging' as a means of maintaining continuous service in advance or in retreat, so that the supreme requirement of getting the wounded early to operation can be fulfilled in all circumstances. In our own North African war, with characteristic capacity for putting a telescope to a blind eye, the British overlooked the rules laid down in the manuals and improvised just such a leap-frogging plan-section by section-to the great betterment of a threatening situation. Necessity, with us, mothered invention; the Russians planned it in advance. Moreover, they have so arranged the segregation of all regional wounds in their forward clearing hospitals, into the care of front detachments of the staff of their head, chest, abdominal, plastic and orthopæedic hospitals, that the patients fall at the earliest moment into the hands of those who will initiate specialist treatment. The same 'teams' will have members away in the far rear, to whom long-stay cases are sent, and thus the whole course of a soldier's invalidity can be controlled and studied by the same specialist staff. There is no doubt that such a system, if the nature of the warfare permits its adoption, is the best devised for saving not so much the life as the full function of the wounded. This, perhaps, is one of the means by which they secure so high a percentage of return to full duty. By contrast with the Soviet success in this respect, one may compare the results on the same ground a century and more ago.

In Napoleon's campaign of 1813, out of 22,000 French soldiers admitted to certain hospitals during May 1-June 1, 6,700 officers and men were known to have returned to active service in their units : just over 30 per cent. Another 20 per cent were capable of some duty; the total figures may have been higher in both categories, but certainly did not approach the modern Russian claim. Moreover, there were 972 amputations in that one month-tragic testimony to the prevalence of gangrene. 2,400 died, that is, more than 10 per cent of those reaching base hospitals. 
These French figures were given by the great military surgeon Larrey, of whom Napoleon said, on leaving him 100,000 franes, that he was the most virtuous man he had known. Of cases reaching our own base hospitals in some recent actions, the deaths were little more than 1 or at most 2 per cent.

I have sat at a table in a clearing hospital behind the front with a woman surgeon wearing five wound stripes, and in the same hospital saw a woman operating on chest cases, of which she had done more than a thousand. Many women doctors have been decorated for bravery. It is perhaps of interest to mention that whereas in peace 50 per cent of medical students are women, now in war they number 85-90 per cent of the 24,000 a year being trained. 16,000 young military doctors, of both sexes, were given special courses in military medicine in 1942.

Another test of efficiency that may be applied is the recognition of problems of major importance in modern military experience. One of the most valuable of all modern methods for saving the life of the wounded soldier is blood transfusion, and here the Russians have been no whit behind us. Their methods for the collection, preservation and distribution of whole blood, their preparation of dried blood constituents for reconstruction in the field, and their many plasma substitutes, indicate very clearly how early and how thoroughly they were seized of the immense life. saving value of this means for controlling 'shock'. A minor measure reveals their appreciation of a psychological factor. The blood is mainly given by women -95 per cent of it, we were told. To the ampoule of blood the name of the girl donor is attached. She knows the wounded Red Army man will hear of her. He knows to whom he is indebted. Romances result and are broadcast for their full propaganda worth. The man who has once benefited, if he be wounded again, asks for the same life-giving blood once more. Blood donors in Great Britain may be interested to know that after tests, and on arrival at the taking station, all women are clothed in sterile garments, caps and masks, before admission to one of the four theatres kept for the four blood groups. They are given a light meal, without fats, just before the blood is drawn. In another station the donor does not enter the theatre at all, but lies upon a couch and thrusts her cleansed arm through a sterilely curtained window into the room where the blood is taken. The arrangements are on a vast scale and thought out to the last detail. As many as eight hundred donors are bled daily in one institute. Tne headquarters of the Blood Transfusion Service has seventy-nine subsidiary institutes under its control, with 1,500 minor stations. Preservation of the blood calls for methods adapted both to the duration required and to the means of transport. When taken by air at high altitudes or in the very low temperatures of winter, special insulating boxes must be used. Distribution is generally by air.

As to other pressing problems, we were fortunate enough to obtain first-hand evidence from distinguished research workers. The Academicians Orbeli and Lena Stern, whose studies have for long been devoted to the elucidation of the functions of the autonomic nervous system, are probably responsible for the orientation of Soviet thought towards neural rather than biochemical predominance in normal and disturbed metabolic functions.

The former, Orbeli, has among other applications of his research, turned to advantage his long studies of the phylogenesis of parts of the nervous system in relation to dark-adaptation of the eye, especially for night-pilots, using his differential study of the rods and cones, and of the Purkinje effect, to that end.

Lena Stern, the only woman Academician, has tackled a problem that still eludes complete solution. It is recognized that in some cases of what we loosely term 'shock', a phase is reached when no amount or kind of transfusion is effective. The dynamics of the circulation have been disturbed to a degree which is 'irreversible'. It is a stage desperate as regards the patient's recovery, and justifies desperate remedy. Stern believes that the 'irreversibility' is dependent upon a complete loss of tone of the musculature of the whole vascular system. She believes that tone is ultimately controlled by centres bordering upon the cerebral ventricles; probably the fourth ventricle particularly. Potassium stimulates the sympathetic and calcium the parasympathetic. She therefore forcibly injects into the cisterna magna, and believes that she thus directs into the ventricle a sterile solution of potassium phosphate; the potassium for its direct effect, the phosphate radical to form, with calcium already present, a non-ionizable and inert compound. An injection into the cisterna magna, except in very expert hands, and in conditions giving guarantees against infection, is not a method to be lightly employed. The syndrome it is sought to remedy is met with within a matter of hours after wounding and exposure; met with, therefore, most frequently before the victim arrives at a wellstabilized hospital, and the remedy must be chiefly useful, at any rate until its value is very thoroughly established, in the hands of experts who reach the forward positions. Prof. Stern stated that a considerable number of reports of success with her method had reached her, but among Russian surgeons generally its use, we gathered, is regarded as experimental. Incidentally, Prof. Stern told us that she had had success with the treatment of tetanus by the cisternal route. In man many severe cases had been cured, and in horses there was a 100 per cent recovery.

As with the Russians, so among the other Allies, the factor of fluid loss in shock has been in the foreground of the picture, but in recent years there have been periods when the neurogenic factor has been enthusiastically pursued here; its importance, however, has never gained unquestioned credence. The 'toxic' factor, to the importance of which Sir Henry Dale directed attention twenty-five years ago, and to the investigation of which his researches lent such impetus, has again come right into the foreground and is engaging a great deal of attention. The Russians have not entirely overlooked this possibility.

We were interested in one method of treatment which runs contrary to all past experience, ours and their own, for frost-bite. It has been the universal practice, of mountaineers as well as soldiers, to avoid rapid warming of parts involved. To rub gently with snow; to warm the rest of the body, perhaps, but to keep the frozen or menaced areas cool. The Russians now put the patients into a well-warmed ward and deliberately heat the frost-bitten limb. They believe in early excision of dead tissue, and, we gathered, in early amputation, and that may possibly be part of the explanation : they cut their losses. But they maintain that their method has a sound physiological basis.

In 1812 Larrey said that the hospitals of Moscow, both military and civil, were the finest he had ever seen. That could not be said to-day of those we saw. The 
buildings are not recent. It is an item to which the Soviet has not yet fully turned its planning attention. When it does so, it is certain that the structures will be determined by function and leave nothing unfit for comparison with the best of other countries. The scale upon which the Russians think is illustrated by their projected great Research Institute, V.I.E.M. It was intended at first to erect it in Leningrad, but afterwards Moscow was decided upon. The plans are, as they themselves say, grandiose. With only five hundred beds for the intensive study of norma] health and somatic disease, they provide approximately a hundred sets of laboratories or departments and 1,300 workers as a beginning. Since every medical student proceeding to an M.D. must present the results of research, which with clinical work normally spreads over six years, the laboratory space, technicians and directors of research must be provided on a great scale. A Red Army convalescent home provides another example of the scope of Russian planning.

When it comes to military hospitals in the forward zone, we were witnesses of their skill in construction, their admirable camouflage, their adaptability and the excellence of their improvisation. It was in a pine forest just beyond Vyasma that we found the clearing hospital already mentioned. We came upon it without realizing that any building, let alone a great hospital, was anywhere near. They also have tented hospitals in the forests - of two hundred bed capacity for each of their specialist departments. Camouflage is essential, since on the Russian fronts the German does not observe the Geneva Convention. It entails two hardships upon the wounded even if the hospitals are not attacked. Smoke must not rise to give away a position and that makes contention with winter cold very difficult. There must be no metalled road running to the site, or the first reconnaissance plane will detect something to be attacked. This means a very uncomfortable and sometimes agonizing ambulance ride over the last mile of track.

We came in contact here with the partisans and guerrillas, who when wounded were regularly fetched in from their concealed collecting points by air. So complete is the organization that dentistry for those behind the German lines seemed quite a natural provision; they make the denture in Moscow, to the mould brought in by air, and fly it back forthwith. The dental department of the Red Army has made enormous numbers of dentures for the troops on every front. In that attached to one facio-maxillary unit we visited, more than a million dentures had been made for soldiers. Artificial limbs, too, are made on a scale commensurate with the size of the armies. Those we saw were entirely constructed of wood, and to our thinking a little on the heavy side, but mechanically good.

No account of medical service in war would be complete without reference to the preparations for dealing with casualties in bombed cities. It is true that we have no towns comparable for utter destruction with Stalingrad and Vyasma, to mention only two that we saw for ourselves, though there are so many others in like plight. But in Moscow there is, judging by experience in Great Britain, little sign of bombardment, and the civil defence arrangements are not so much in evidence. We saw one control room, which had been used for bomb casualties, but it existed in peace, and enables every accident or acute emergency in Moscow to be brought to the great emergency hospital or to one of its six satellites. We watched three calls. From the receipt of the message to the dispatch of an ambulance with nurse and doctor aboard, the average time was one minute forty seconds. It would be difficult to better such a system, but I must add that with our own bitter experience in mind, I was disappointed to be told they had no organized messenger service to replace the telephones when an unlucky or well-directed bomb fell upon the exchange. I have no doubt that had the need arisen in Moscow a service would immediately have been improvised, and I expect Leningrad would tell a different tale.

Among the men responsible for Soviet achievement in the section of their life under review there are three whom we met whose characters suggest the basic reason for success.

The director-general of the medical corps of all the Russian armies, Lieut.-General Smirnov, is a man of thirty-seven. He is a big, fair man whose face can be expressive of determination, of irony, of humour. It is stated that as a child and youth he had no education and was employed in labouring work. Between twenty and twenty-four he fitted himself to enter a medical school. He qualified at twenty-nine. In eight years his ability has raised him to the highest administrative post in the medical services, and we were informed by an Academician that, in addition, his purely professional attainments were held in high esteem by men of science and practitioners alike.

The chief consultant surgeon, Lieut.-General Burdenko, is a man whose energy has enabled him to triumph over a personal disaster to his health that would have ended the career of a lesser man. $\mathrm{He}$ has inspired in his pupils and his assistants an unassailable devotion. It is evident that his opinion has moulded current military medical thought and practice. His own particular interest has been neurosurgery, and it is to him that is owing the very active research in that department now so fruitful in Russia. $\mathrm{He}$ told us with pride that from front line to far base he had seven thousand beds for neuro-surgery, and we had evidence from Profs. Rappaport, PropperGrashenko and Schlikov of the intensive study devoted to the occupants of his wards. Operative surgery on the central and peripheral nervous systems as we saw it practised is perhaps lacking in the refinements now the rule in American and British units, but the neuro-surgeons with us recognized that some of the records made at the front were as good as any they had ever seen, and they felt that the skill and ability were not lacking in the young men to permit their quickly reaching the highest proficiency.

In Prof. Yudin, head of the famous Sklissosovsky Hospital for accidents and acute emergencies in Moscow, Russia has an abdominal surgeon who would lend distinction to any clinic in the world. His experience is immense ; in some respects unique. His courage is matched by his gentleness; his skill by his untiring devotion. It is characteristic that in war he should go often to the front and there devote his abilities to perfecting and teaching others the technique by which that most disabling of curable wounds, compound fracture of the femur, can best be treated. Watching this man at work, studying the conditions of work he has created about him to ensure success, seeing the subjects of his most daring and extensive operations a week after operation, we could not but feel that the service which has such a man, nay, such men, has a source of inspiration 
which has carried it far, and will lead it to great heights.

Russian military medical officers have maintained their armies in the field without the occurrence of any epidemic disaster; they have enabled their soldiers successfully to use the most powerful and elaborate of war machines ; they have cared for the wounded so skilfully as to obtain a record recoveryrate; and they have sustained the morale of their troops through a period of devastating tribulation to the dawn of a triumphant advance.

What more could be asked of the army medical corps of any nation?

\section{INTER-RELATIONS OF PLANTS AND INSECTS}

$\mathrm{I}^{\mathrm{N}}$ opening a joint discussion on "The Inter-relations of Plants and Insects : the Place of Both in the Eco-system" between the British Ecological Society and the Royal Entomological Society of London held on November 12, Prof. E. J. Salisbury claimed that though the insect - flower relations have been extensively studied, the quantitative aspects of insectpollination have been little explored though economically important, while the competition aspect has been largely ignored. The elaborate and familiar relation between the yucca moth Pronuba and Yucca filamentosa, in which the reproduction of each is dependent on the other, but the larvæ take a high percentage of potential ovule production, serves to illustrate how narrow may be the margin between benefit and disadvantage in the relations between insects and plants.

The relations of insects to plants as pests or predators set many questions that require answers. Why, for example, are some insects almost omnivorous, whereas others are confined to particular species? Familiarity with human preferences obscures the fundamental problems waiting to be investigated. Something of the complexity of the problem is indicated by insect larvæ which in the wild state are found on one food-plant only but in captivity can be reared on a variety of species. An analysis of the physiological basis for such preferences might well yield data of great practical importance in the field of horticulture and agriculture. Whether a plant species in the British Isles supports the same insect population as the same kind of plant in continental Europe is also a matter of great biological interest. For the nature and variety of the insect predators and pests to which a plant species in Britain is subject may be an important indication as to the length of time that the plant has been present in these islands or, on the other hand, as to the efficiency of insect dispersal.

The influence of man has created in the past, and is constantly creating in the present, habitat conditions where the pressure of competition is reduced or even negligible, and the species associated with the arrested successions thus artificially maintained have been frequently regarded as under suspicion of being introductions. But the species which to-day we find most frequently occurring in, or even confined to, artificial conditions, may be those which in former times were to be met with in similar though much less frequent conditions created by natural agencies. On the other hand, they may represent what may be termed domestic species which have arisen since the widespread occurrence of such habitats, and in some instances may have extended into natural habitats of a similar character. This might appear to have little concern with the relations between plants and insects were it not that both groups of organisms present the same general problem, and an intensive study from this point of view of such very interesting series as that presented by the group of house spiders and their allies might well shed light on the fundamental problem. The domesticated flora and fauna not only deserve more attention than they have hitherto received, but also attention to the relations of both might reveal what the study of either alone could not achieve.

Dr. E. A. Cockayne discussed a number of Macrolepidoptera which are limited by special plant species. Many species of moth are attached to a genus rather than to a species, and others eat two or three plants belonging to allied genera, such as Fraxinus and Ligustrum, Calluna and Erica, Urtica and Humulus, Silene maritima and Spergularia. Oak has more species of Macrolepidoptera restricted to it than any other plant ; they are eighteen in number and belong to several families. In the case of many larvæ limited to a single plant species, the latter is the only representative of the genus found in Great Britain, but on the Continent, where other members of the genus occur, these also are eaten; for example, Bupalus. piniaria is confined to Pinus sylvestris in Britain, but eats other species of Pinus on the Continent. Other examples of genera with only one native species are Fagus with one species of moth restricted to it; Alnus with two; Clematis with five; Euphrasia with two; Eupatorium with one; Serratula with one; Solidago with two; Phragmites with nine; Elymus with one; Ammophila with one. On the other hand, Ulmus campestris has two species peculiar to it and Ulmus montana has two others; Carex glauca has one; Calamagrostis epigeios has two; Festuca arundinacea has one; Deschampsia coespitosa has one; Artemisia absynthium has one, and A. maritima has two; Lysimachia vulgaris has one, and Convolvulus arvensis has three. In such cases the selection of one species of a genus is usually due to a difference in ecological conditions.

It is interesting that most British moths with a very restricted range are not restricted because of the absence of a special food-plant. Anepia irregularis, however, has the same narrow range on the Breck sand as its food-plant, Silene otites, and it is probable that the limited south-western range of Drepana harpagula is coterminous with that of Tilia parvifolia.

Some British Lepidoptera have reached the northern or western extremity of their distribution and have become limited to special ecological conditions or to a special food-plant. Papilio machaon is found only in the Fens, and feeds chiefly on Peucedanum palustre; while abroad it is found in all kinds of country and feeds on many umbellifers ; Malacosoma castrensis, an inland and woodland species on the Continent, is only found in the salt-marshes of south-eastern England, though it feeds on most of the plants which grow there. Brachionycha nubeculosa, which feeds on many kinds of tree abroad, only eats Betula alba in its local haunts in the Highlands of Scotland.

There are instances of biological races with different food-plants. Eupithecia denotata eats the seeds of Campanula trachelium. and its race $E$. jasioneata eats those of Jasione montana, while Hydrelia flammeolaria eats maple in the south and alder and mountain ash 